
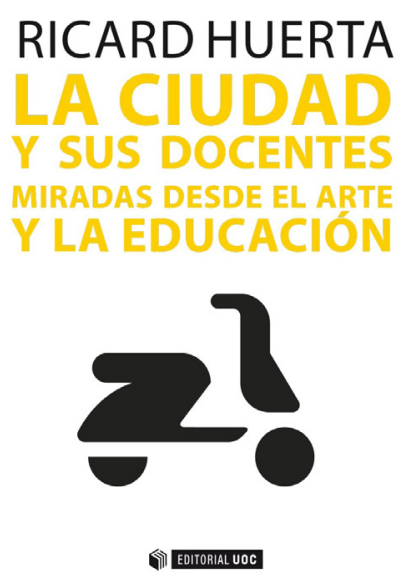

La ciudad y sus docentes. Miradas desde el arte y la educación

Ricard Huerta

Año: 2015 Lugar: Barcelona

Editorial UOC Páginas: 213

ISBN: 978-84-9064-584-0

\title{
A despertar conciencias
}

En la actualidad, más de la mitad de la población mundial vive en ciudades, pero las previsiones que plantea el último informe del Programa de Naciones Unidas para los Asentamientos Humanos (ONU-HABITAT) afirma que esta cifra podría estar alrededor del $70 \%$ en el 2050. Según este informe a medida que las ciudades aumenten su tamaño y población será cada vez más importante la armonía entre las características espaciales, sociales y ambientales del espacio urbano y su relación con los ciudadanos. La ciudad posee elementos de gran riqueza perceptiva como texturas, colores, formas, olores, sonidos. Podemos afirmar que las ciudades se convierten en grandes escenarios que integran aspectos creativos, estéticos, históricos, urbanísticos y donde confluyen las experiencias vitales de sus ciudadanos, sus relaciones, sus recuerdos y proyectos. El poder de fascinación de las ciudades es generador de múltiples miradas, de tal modo que podemos hablar de una mirada estética, literaria, urbanística, sociológica, etc. Pero, ¿existe una mirada pedagógica hacia lo urbano?

Partiendo de esta cuestión el último libro del profesor Ricard Huerta, La ciudad y sus docentes. Miradas desde el arte y la educación, publicado por la editorial de la Universitat Oberta de Catalunya, indaga en la mirada particular que los docentes tienen sobre la ciudad en la que viven y trabajan. El libro trata sobre identidades y patrimonios, dos elementos que articulan gran parte de la obra de Huerta, tal como podemos ver en libros anteriores como Maestros y museos. Educar desde la invisibilidad o Mujeres maestras. Identidades docentes en Iberoamérica.

Huerta realiza también una reivindicación del docente como un poderoso referente cultural y social que debería tener mayor influencia y visibilidad. Entendiendo el entorno y la ciudad como espacios educativos se observa la importancia de despertar una conciencia ciudadana y de la labor del docente. Moacir Gadotti en la Primera Conferencia Internacional de educación celebrada en Riberao Preto San 
Pablo (Brasil, julio 2002) afirmaba que "en general ignoramos la ciudad, reducimos nuestro observar y no la percibimos, y algunas veces hasta la escondemos, damos la espalda para no ver ciertas cosas que suceden en ella". Las desigualdades crecientes en nuestra sociedad, los fenómenos migratorios, el acceso a la vivienda o a la sanidad universal, son cuestiones que no pueden caer en la "invisibilidad". Huerta nos plantea también cómo desde la educación artística se puede contribuir a una sociedad más justa y libre, contribuyendo al desarrollo de una visión crítica y creativa sobre los espacios que respete el hecho diferencial y ponga en valor el patrimonio cultural propio. Este despertar de conciencias es un reto educativo y un camino para hacer posible la construcción de la ciudad como un proyecto compartido.

Desde los postulados de la cultura visual el libro La ciudad y sus docentes recoge las opiniones de los docentes en torno a la ciudad en la que desarrollan su trabajo. Cuestiones como cómo definirían su ciudad, conocer los referentes culturales de su ciudad o la valoración que realizan sobre su papel en la formación de ciudadanía, nos posibilita un acercamiento a sus docentes y su coyuntura. La utilización de una metodología de investigación basada en las artes introduce también elementos de reflexión y creación a partir de la participación de los profesores en acciones artísticas. La expresión a través de medios artísticos de las propias vivencias, la experimentación e interpretación de los espacios públicos en base a sus significados estéticos y visuales contribuye al desarrollo de habilidades críticas para valorar la calidad del espacio urbano y el patrimonio cultural. En este recorrido que nos presenta Huerta se recogen las experiencias llevadas a cabo con docentes de cinco ciudades: Buenos Aires, Lima, Montevideo, Santiago de Chile y Valencia. Junto a ello el relato se enriquece con múltiples referencias vinculadas a la pedagogía, la estética, el arte, la cultura visual, la literatura, el cine, la sociología y el urbanismo.

El resultado no sólo nos acerca a la mirada propia de los docentes hacia lo urbano, sino que más allá reivindica el papel del profesorado y su responsabilidad como poderoso referente cultural y social, ya que de su implicación individual o colectiva depende el éxito o la visibilidad de muchas propuestas que llegan con energía desde la sociedad. 